\title{
Keratoderma blennorrhagica
}

\author{
Ilda Coelho, Sara Costa, Sofia Silva Mendes, Guilherme Castro Gomes
}

Department of Internal Medicine, Hospital de Braga, Braga, Portugal

\section{Correspondence to} Dr llda Coelho ilda_coelho@hotmail.com

Accepted 3 November 2017

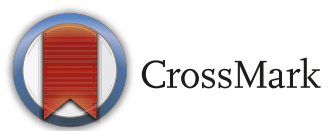

To cite: Coelho I, Costa $S$, Mendes SS, et al. BMJ Case Rep Published Online First: [please include Day Month Year]. doi:10.1136/bcr-2017222475

\section{DESCRIPTION}

A 26-year-old woman, previously healthy, that a month ago started complaining of pain in the soles of both feet, which followed, additionally, to the right knee, the left knee, left elbow and right shoulder. She reported morning stiffness exceeding 1 hour that decreased with physical activity, worsened with rest, but improved with administration of non-steroidal anti-inflammatory drugs (NSAIDs). Three weeks later, skin lesions appeared on the soles of the feet.

Seven to 8 weeks before, the patient would have had two successive episodes of a urinary tract infection, treated, respectively, with fosfomycin and ciprofloxacin. The patient did not present gastrointestinal symptoms, previous weight loss or sweating.

On physical exam, it was verified pain at knee mobilisation, more intense in the left, where it presented articular effusion.

The cutaneous lesions were about $0.5 \mathrm{~cm}$ in diameter, were maculopapular, on a background of diffuse erythema and of desquamation on large blades (figure 1); no other skin lesions were observed.

Microbial examinations, including urine culture, blood cultures, urethral swab and synovial fluid, were negative. The research of Chlamydia trachomatis, Ureaplasma urealyticum, Gonococcus and Treponema pallidum by PCR did not document previous infection. Analyzing the remaining tests, it was found to be positive for the human leucocyte antigen (HLA)-B27.

It was concluded that the most likely diagnosis was reactive arthritis (ReA) or Reiter's arthritis, whereby the patient was treated with doxycycline and rifampicin for 3 months in association with sulfasalazine and the remaining symptomatic treatment with NSAIDs.

Complete resolution of skin complaints and lesions was verified 1 month after the diagnosis, and in the follow-up, there were no new symptomatic complaints or cutaneous lesions that might suggest other differential diagnoses, namely, psoriatic arthritis.

ReA is a spondyloarthropathy resulting from cross-reactivity antigens, usually triggered by

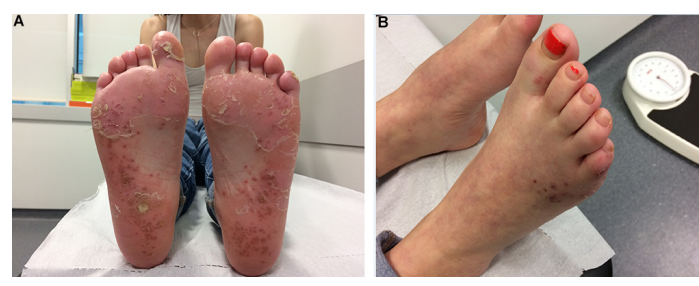

Figure 1 Detailed view of maculopapular erythematous and desquamative lesions present on sole $(A)$ and back (B) of the patient's feet, characteristic of blennorrhagic keratoderma. gastrointestinal or genitourinary infections, most often by C. trachomatis, Yersinia or Salmonella. ${ }^{1}$

It is characterised by musculoskeletal attainment, being able to reach several joints, more frequently knees and ankles. ${ }^{2}$ It may be associated with ocular and cutaneous manifestations, such as balanitis circinata or, less frequently, blennorrhagic keratoderma. ${ }^{13}$

The diagnosis of ReA is presumptive and based on clinical features, namely by the correlation between recent genitourinary or gastrointestinal infections, asymmetric oligoarthritis and other possible extra-articular manifestations, such as enthesopathy or ocular inflammation. ${ }^{2}$

The acknowledgement of the dermatological picture of blennorrhagic keratoderma in an appropriate clinical setting greatly facilitates proper diagnosis and treatment.

The presence of HLA-B27, in addition to increasing susceptibility, seems to be associated with more severe forms and chronic evolution.

The use of antibiotic therapy should be considered when there is evidence of infection, and its efficacy depends on the causal agent of the disease. Enteric infection treatment is only indicated in the presence of active infection, with the most suitable drugs being ciprofloxacin or sulfamethoxazoletrimethoprim. In patients with genitourinary tract infection, the use of tetracycline or derivatives and the treatment of sexual partners are essential to prevent reinfestation.

As urogenital Chlamydia infection is often asymptomatic, it is prudent to investigate patients with diagnosis of ReA with no defined causal factor.

\section{Learning points}

The diagnosis of reactive arthritis is presumptive and based on clinical features, usually related to the correlation between recent genitourinary or gastrointestinal infections.

- Recognition of blenorrhagic keratoderma in an appropriate clinical setting greatly facilitates proper diagnosis and treatment.

- The presence of human leukocyte antigen-B27, in addition to increasing susceptibility, seems to be associated with more severe forms and chronic evolution.

Contributors IC substantially contributed to the conception, design of the work, the acquisition, analysis and interpretation of data and the final approval of the version published. SC and SM contributed substantially to the acquisition, analysis and interpretation of data and the final approval of the version published. GG contributed to the analysis and interpretation of data, in revising it critically for important intellectual content and in the final approval of the version published.

Competing interests None declared. 
Patient consent Obtained.

Provenance and peer review Not commissioned; externally peer reviewed.

(C) BMJ Publishing Group Ltd (unless otherwise stated in the text of the article) 2017. All rights reserved. No commercial use is permitted unless otherwise expressly granted.

\section{REFERENCES}

1 Carter JD, Hudson AP. Reactive arthritis: clinical aspects and medical management. Rheum Dis Clin North Am 2009:35:21-44.

2 Kataria RK, Brent LH. Spondyloarthropathies. Am Fam Physician 2004;69:2853-60.

3 Krajewska-Włodarczyk M, Owczarczyk-Saczonek A, Placek W. Cutaneous manifestation of reactive arthritis: Case report. Polish Annals of Medicine 2015;22:132-5.

Copyright 2017 BMJ Publishing Group. All rights reserved. For permission to reuse any of this content visit

http://group.bmj.com/group/rights-licensing/permissions.

BMJ Case Report Fellows may re-use this article for personal use and teaching without any further permission.

Become a Fellow of BMJ Case Reports today and you can:

- Submit as many cases as you like

- Enjoy fast sympathetic peer review and rapid publication of accepted articles

- Access all the published articles

Re-use any of the published material for personal use and teaching without further permission

For information on Institutional Fellowships contact consortiasales@bmjgroup.com

Visit casereports.bmj.com for more articles like this and to become a Fellow 